Vegetalika. 2018. 7(4): 74-88

\title{
Pemilihan Alternatif Pohon Buah Untuk Penghijauan Berdasar Karakteristik Tanaman Dan Kesesuaian Lahan Di Area Perkantoran Pemda Bantul, Manding, Yogyakarta
}

\section{Study on Fruit Trees for Greenery in Office Based on Plant Characteristic and Land Suitability for Office in Bantul Local Government Office Area, Manding, Yogyakarta}

\author{
Yogyaning Kartiko Atmojo, Siti Nurul Rofiqo Irwan*), Rohlan Rogomulyo, \\ Departemen Budidaya Pertanian, Fakultas Pertanian, Universitas Gadjah Mada \\ *) Penulis untuk korespodensi E-mail: rofiqoirwan@ugm.ac.id
}

\begin{abstract}
Fruit trees can be used as urban greenery to increase added values and co create the Local Government Office Area. The main aim of this research was to selecting of fruit trees alternative based on plant characteristics for office and land suitability. The research was conducted by survey on existing location using simple random sampling method to get the appropriate sample for revitalizazion program which held by environmental services. The result showed that greening with fruit trees are suitable for Bantul Local Government Office Area with concern of guests or office visitors zone. First welcome area zone which suitable for tamarind (Tamarindus indica), Kepel fruit (Stelechocarpus burahol), langsat (Lansium domesticum). Second is main activity zone which suitable for longan (Euphoria longan), star apple (Chrysophyllum cainito), jambolan (Syzygium cumini), and pulasan (Nephelium mutabile). And the last is guest/visitors facilities zone which suitable for dersono guava (Eugenia malaccensis), and langsat (Lansium domesticum).
\end{abstract}

Keywords: greenery, fruit trees, zone.

\section{INTISAR}

Pohon buah dapat digunakan sebagai alternatif penghijauan di area perkantoran untuk menambah fungsi tanaman dalam penghijauan. Penelitian ini bertujuan untuk melakukan seleksi alternatif pohon buah untuk penghijauan berdasarkan karakteristik tanaman perkantoran dan kesesuaian lahan di area perkantoran Pemda Bantul. Penelitian ini dilakukan dengan survei lokasi existing, pengambilan sampel tanah dengan simple random sampling dilakukan agar mendapat sampel tanah yang sesuai dengan lokasi program revitalisasi dinas Lingkungan Hidup. Hasil penelitian menunjukkan terdapat pohon buah yang sesuai untuk dimanfaatkan sebagai penghijauan di area Perkantoran Pemda Bantul dengan memperhatikan zona aktivitas tamu atau pengunjung perkantoran. Alternatif pohon buah pada zona penerimaan antara lain Asam Jawa (Tamarindus indica), Kepel (Stelechocarpus burahol), Duku (Lansium domesticum). Kemudian pada zona inti aktivitas direkomendasikan alternatif pohon buah Lengkeng (Euphoria longan), Sawo Duren (Chrysophyllum cainito), 
Jamblang (Syzygium cumini), dan Kapulasan (Nephelium mutabile). Selanjutnya pada zona fasilitas masyarakat direkomendasikan alternatif pohon buah Jambu dersono (Eugenia malaccensis), dan Duku (Lansium domesticum)

Kata Kunci: Penghijauan, pohon buah, zona.

\section{PENDAHULUAN}

Ruang terbuka hijau memiliki manfaat yang sangat besar terhadap lingkungan perkotaan, baik dari segi ekologi maupun segi ekonomi. Ruang terbuka hijau tidak dapat terlepas dari vegetasi penyusun yang berada didalamnya. Penentuan tanaman penyusun di lahan spesifik sangat ditentukan oleh keadaan iklim dan tanah agar dapat tumbuh dan berkembang secara optimal. Area perkantoran merupakan salah satu bentuk RTH yang diatur dalam Peraturan Menteri (Permen) perkerjaan umum no 5 tahun 2008.

Vegetasi tegakan pohon dengan pohon buah memiliki dampak positif pada area terbuka. Pohon buah dapat menjadi titik pusat perhatian di ruang terbuka hijau, ornamen buah yang berwarna menjadi perhatian masyarakat dan memilih untuk berteduh dibawahnya. Ditambah lagi bahwa pohon buah dapat meningkatkan biodiversitas pada area ruang terbuka hijau dan meningkatkan ketertarikan suatu ruang terbuka (Lisandru et. al., 2016). Vegetasi penghijauan area perkantoran Pemda Bantul terdiri $27,2 \%$ jenis pohon buah dari populasi total pohon penghijauan. Ditambah data menurut kepala bidang III Pemda Lingkungan Hidup Bantul, pohon buah menjadi pilihan Pemda Lingkungan Hidup Bantul dalam melakukan revitalisasi tanaman tiap tahunnya di area perkantoran Bantul.

Penyusunan alternatif pohon buah pada RTH dibutuhkan kesesuaian terhadap biogeografis pada lahan spesifik (Dunnet, et.al. 2002). Kondisi tersebut dapat diketahui dengan kualitas dan karakteristik lahan. Oleh karena itu diperlukan pendekatan agronomi dari sisi pemilihan pohon buah dengan kesesuaian lahan terhadap kondisi lingkungan yang ada. Hasil kesesuaian lahan akan disempurnakan dengan pedoman penyediaan dan pemanfaatan ruang terbuka hijau khususnya di kawasan perkantoran menurut Peraturan Menteri no 5 tahun 2008.

\section{BAHAN DAN METODE PENELITIAN}

Pengambilan data dilakukan pada bulan September-Desember 2017 di area perkantoran Pemda Bantul, Manding Bantul, Daerah Istimewa Yogyakarta. Objek 
Yogyaning Kartiko Atmojo et al., / Vegetalika. 2018. 7(4): 74-88

penelitian berupa pohon buah alternatif yang disusun berdasarkan kesesuaian ketinggian tempat penelitian dan di analisis menggunakan kriteria tanaman perkantoran dan kesesuaian lahan di area perkantoran Pemda Bantul Penelitian dilakukan dengan survei, melalui tahap persiapan, observasi, investigasi, anlisis data dan perumusan rekomendasi (modifikasi Beer,1990).

Tahap persiapan dilakukan dengan menyusun daftar alternatif pohon buah berdasarkan kesesuaian ketinggian tempat untuk penghijauan di area perkantoran Pemda Bantul. Serta data iklim meliputi temperatur rerata, curah hujan dan kelembaban selama 10 tahun terakhir yang diambil dari BMKG DIY,

Observasi dilakukan untuk pengambilan data sampel tanah yang menggunakan metode simple random sampling. Area sampel tanah dibagi menjadi 3 area kemudian setiap area diambil 5 titik. Setiap area sampel dikomposit sehingga didapati 3 komposit area sampel. Pengambilan sampel tanah dilakukan pada kedalaman tanah 0-25 dan 25-50. Metode pengambilan sampel tanah secara random dilakukan dengan pertimbangan didekat vegetasi pohon yang tidak berada pada area perkerasan. Pengujian sifat fisik digunakan metode dengan analisis tekstur di lapangan. Kemudian untuk uji sifat kimia tanah meliputi Penetapan $\mathrm{pH}$ tanah dengan metode $\mathrm{pH}$ meter, $\mathrm{N}$ total dengan metode Kjedahl, P-total dan K-tersedia dengan metode ekstrak HCL 25\%, KPK dengan metode Amonium Asetat, Kation Tersedia Ca, Mg dengan metode AAS, kation tersedia $\mathrm{K}$, Na dengan metode Flamefotometer, C-organik dengan metode Walkey \& Black, Kejenuhan basa dan Sodisitas

Investigasi dilakukan untuk matching skor kesesuaian lahan setiap alternatif pohon buah. pemilihan tanaman buah berdasarkan analisis kesesuaian lahan dilakukan dengan pendekatan analisis keterpautan (matching), yaitu mengaitkan antara kualitas dan karakteristik lahan terhadap kriteria alternatif pohon buah masingmasing spesies yang diperoleh dari pustaka, serta hasil pengujian sampel tanah di laboratorium. Kriteria kesesuaian lahan yang dikembangkan oleh Sys et.al, (1993) adalah dengan membuat hubungan liner antara limitasi/faktor pembatas lahan dengan klasifikasi kesesuaian lahan, serta membuat determinasi kesesuaian lahan dengan sistem kriteria (Alam, 2014 cit Sys et.al, 1993).

Analisis data yang digunakan mengacu model Miles dan Huberman (1984) yaitu menggunakan reduksi data yang berulang sebagai tahapan seleksi tanaman sehingga data bersifat jenuh dan dapat ditarik kesimpulan. Perumusan rekomendasi alternatif pohon buah didasarkan atas zona-zona yang telah ditentukan berdasarkan aktivitas tamu/pengunjung perkantoran. 


\section{HASIL DAN PEMBAHASAN}

\section{Kualitas dan Karakteristik Lahan}

Area Perkantoran Pemda Manding Bantul merupakan hamparan yang terbentuk oleh modifikasi dengan tanah urug. Hal tersebut menyebabkan jenis tanah kondisi existing akan berbeda pada peta tanah Bantul. Berdasarkan Dinas Pekerjaan Umum tanah yang digunakan untuk modifikasi hamparan tersebut berasal dari Bangunjiwo, Kasihan, Bantul. Penentuan sifat fisika tanah berupa tekstur diamati pada lokasi penelitian dengan cara pendugaan sifat tanah yang berpedoman pada segitiga tekstur tanah. Untuk sifat kimia pada retensi hara $\left(\mathrm{KPK}, \mathrm{pH} \mathrm{H}_{2} \mathrm{O}, \mathrm{C}\right.$-organik) dan hara tersedia ( $\mathrm{N}, \mathrm{P}_{2} \mathrm{O}_{5}, \mathrm{~K}_{2} \mathrm{O}$ ) dilakukan pengujian tanah di BPTP Yogyakarta (Tabel 1).

Pengujian kualitas dan karakteristik lahan dilakukan terhadap 3 area sampel. Hal tersebut dilakukan untuk menghindari sifat heterogen tanah yang ada di area perkantoran Pemda Bantul. Adapun terdapat tiga area sampel yang diuji namun nilai karakteristik lahan yang tidak berbeda terlalu jauh. Untuk itu dilakukan analisis kesesuaian dengan nilai rata-rata dari ketiga area. Harkat penggolongan kriteria anasir kualitas dan karakteristik lahan berpedoman pada staf pusat penelitian tanah tahun 1993 yang diambil dari Hardjowigeno dan Widiatmaka (2007). 
Yogyaning Kartiko Atmojo et al., / Vegetalika. 2018. 7(4): 74-88

Tabel 1. Kualitas dan Karakteristik Lahan Area Perkantoran Pemda Bantul

\begin{tabular}{|c|c|c|c|c|c|c|c|}
\hline No & $\begin{array}{c}\text { Kualitas dan Karakteristik } \\
\text { Lahan }\end{array}$ & $\begin{array}{l}\text { Nilai } \\
\text { Data } \\
\text { area } 1\end{array}$ & Harkat & $\begin{array}{l}\text { Nilai } \\
\text { Data } \\
\text { area } 2\end{array}$ & Harkat & $\begin{array}{c}\text { Nilai } \\
\text { Data } \\
\text { area 3 }\end{array}$ & Harkat \\
\hline 1 & Temperatur (tc) & & & & & & \\
\hline 2 & $\begin{array}{l}\text {-Temperatur rerata (s) } \\
\text { Ketersediaan air (wa) }\end{array}$ & 26.11 & & 26.11 & & 26.11 & \\
\hline 3 & $\begin{array}{l}\text {-Bulan kering (Bulan) } \\
\text {-Curah hujan tahun (mm) } \\
\text {-Kelembaban (\%) } \\
\text { Ketersediaan oksigen }\end{array}$ & $\begin{array}{l}4 \\
3439.1 \\
82.29\end{array}$ & & $\begin{array}{l}4 \\
3439.1 \\
82.29\end{array}$ & & $\begin{array}{l}4 \\
3439.1 \\
82.29\end{array}$ & \\
\hline & -drainase & $\begin{array}{l}\text { agak } \\
\text { baik }\end{array}$ & & $\begin{array}{l}\text { agak } \\
\text { baik }\end{array}$ & & $\begin{array}{l}\text { agak } \\
\text { baik }\end{array}$ & \\
\hline 4 & $\begin{array}{l}\text { Media Perakaran (rc) } \\
\text {-tekstur tanah }\end{array}$ & $\begin{array}{l}\text { agak } \\
\text { halus, } \\
\text { halus }\end{array}$ & $\begin{array}{l}\text { lempung, } \\
\text { geluh } \\
\text { lempung }\end{array}$ & $\begin{array}{l}\text { agak } \\
\text { halus, } \\
\text { halus }\end{array}$ & $\begin{array}{l}\text { lempung, } \\
\text { geluh } \\
\text { lempung }\end{array}$ & $\begin{array}{l}\text { agak } \\
\text { halus, } \\
\text { halus }\end{array}$ & $\begin{array}{l}\text { lempung, } \\
\text { geluh } \\
\text { lempung }\end{array}$ \\
\hline 5 & Retensi hara (nr) & & & & & & \\
\hline & $-\mathrm{KPK}(\mathrm{cmol}(+) / 100 \mathrm{~g})$ & 41.51 & tinggi & 38,29 & tinggi & 39.07 & tinggi \\
\hline & $-\mathrm{pH} \mathrm{H} \mathrm{H}_{2} \mathrm{O}$ & 6.5 & $\begin{array}{l}\text { agak } \\
\text { masam }\end{array}$ & 6.9 & netral & 6.3 & $\begin{array}{l}\text { agak } \\
\text { masam }\end{array}$ \\
\hline 6 & $\begin{array}{l}\text {-Kejenuhan basa (\%) } \\
\text {-C-organik (\%) } \\
\text { Hara tersedia (na) }\end{array}$ & $\begin{array}{l}30,35 \\
1.2\end{array}$ & $\begin{array}{l}\text { rendah } \\
\text { rendah }\end{array}$ & $\begin{array}{l}30,27 \\
1.5\end{array}$ & $\begin{array}{l}\text { rendah } \\
\text { rendah }\end{array}$ & $\begin{array}{l}30,94 \\
1.1\end{array}$ & $\begin{array}{l}\text { rendah } \\
\text { rendah }\end{array}$ \\
\hline 7 & $\begin{array}{l}-\mathrm{N} \text { total }(\%) \\
-\mathrm{P}_{2} \mathrm{O}_{5}(\mathrm{mg} / 100 \mathrm{~g}) \\
-\mathrm{K}_{2} \mathrm{O}(\mathrm{mg} / 100 \mathrm{~g}) \\
\text { Sodisitas }(\mathrm{xn})\end{array}$ & $\begin{array}{l}0.18 \\
18 \\
22\end{array}$ & $\begin{array}{l}\text { rendah } \\
\text { rendah } \\
\text { sedang }\end{array}$ & $\begin{array}{l}0.22 \\
25 \\
29\end{array}$ & $\begin{array}{l}\text { sedang } \\
\text { rendah } \\
\text { sedang }\end{array}$ & $\begin{array}{l}0.15 \\
19 \\
18\end{array}$ & $\begin{array}{l}\text { rendah } \\
\text { rendah } \\
\text { rendah }\end{array}$ \\
\hline & -Alkalinitas (\%) & 0,674 & rendah & 0,496 & rendah & 0,537 & rendah \\
\hline 8 & $\begin{array}{l}\text { Bahaya erosi (eh) } \\
\text {-Lereng (\%) } \\
\text {-Erosi }\end{array}$ & $\begin{array}{l}0-2 \\
<0.15\end{array}$ & $\begin{array}{l}\text { datar } \\
\text { sangat } \\
\text { ringan }\end{array}$ & $\begin{array}{l}0-2 \\
<0.15\end{array}$ & $\begin{array}{l}\text { datar } \\
\text { sangat } \\
\text { ringan }\end{array}$ & $\begin{array}{l}0-2 \\
<0.15\end{array}$ & $\begin{array}{l}\text { datar } \\
\text { sangat } \\
\text { ringan }\end{array}$ \\
\hline 9 & $\begin{array}{l}\text { Bahaya genangan } \\
\text {-Tinggi genangan } \\
\text {-Lama genangan }\end{array}$ & $\begin{array}{l}5-10 \\
\mathrm{~cm} \\
<1 \text { hari }\end{array}$ & $\begin{array}{l}\text { ringan } \\
\text { ringan }\end{array}$ & $\begin{array}{l}5-10 \\
\mathrm{~cm} \\
<1 \text { hari }\end{array}$ & $\begin{array}{l}\text { ringan } \\
\text { ringan }\end{array}$ & $\begin{array}{l}5-10 \\
\mathrm{~cm} \\
<1 \text { hari }\end{array}$ & $\begin{array}{l}\text { ringan } \\
\text { ringan }\end{array}$ \\
\hline
\end{tabular}

1) Rerata data iklim 10 tahun terakhir (2007-2016) diambil dari badan meterologi klimatologi dan geofisika (BMKG) DIY

2) Data anasir tanah didapatkan dari hasil analisis tanah Badan Penelitian dan Pengembangan Pertanian (BPTP) DIY (2017)

3) Harkat menurut Hardjowigeno dan Widiatmaka (2007)

Pada Tabel 1. ditunjukkan bahwa curah hujan di area penilitian tergolong tinggi, akan tetapi sifat fisika tanah yang berupa tekstur lempung dan geluh lempungan mempunyai luas permukaan yang besar sehingga kemampuan menahan air tinggi. Ditambah lagi tingkat kemiringan lereng yang rendah atau datar menjadikan daerah penelitian ini memiliki harkat bahaya erosi yang ringan. 
Yogyaning Kartiko Atmojo et al., / Vegetalika. 2018. 7(4): 74-88

Menurut Alam (2014) dikatakan bahwa bahaya erosi dipengaruhi oleh keadaan sifat tanah, terrain (lereng) dan iklim (curah hujan). Tabel 1 menunjukkan bahwa curah hujan di area penilitian tergolong tinggi, akan tetapi sifat fisika tanah yang berupa tekstur lempung dan geluh lempungan mempunyai luas permukaan yang besar sehingga kemampuan menahan air tinggi. Ditambah lagi tingkat kemiringan lereng yang rendah atau datar menjadikan daerah penelitian ini memiliki harkat bahaya erosi yang ringan.

Tabel 2. Unsur kation pembentuk tanah area perkantoran Pemda Bantul

\begin{tabular}{lcccc}
\hline $\begin{array}{l}\text { Sampel } \\
\text { Tanah }\end{array}$ & $\begin{array}{c}\mathrm{Ca} \\
(\mathrm{me} / 100 \mathrm{~g})\end{array}$ & $\begin{array}{c}\mathrm{Mg} \\
(\mathrm{me} / 100 \mathrm{~g})\end{array}$ & $\begin{array}{c}\mathrm{K} \\
(\mathrm{me} / 100 \mathrm{~g})\end{array}$ & $\begin{array}{c}\mathrm{Na} \\
(\mathrm{me} / 100 \mathrm{~g})\end{array}$ \\
\hline Area 1 & 11.22 & 0.98 & 0.12 & 0.28 \\
Area 2 & 10.09 & 1.12 & 0.19 & 0.19 \\
Area 3 & 10.97 & 0.82 & 0.09 & 0.21 \\
\hline *Data Pengujian Tanah BPTP (2017) & &
\end{tabular}

Kapasitas pertukaran kation (KPK) merupakan ukuran kemampuan tanah untuk menjerap dan menukar kembali kation dari dan ke dalam larutan tanah. Besaran harkat kpk dalam tanah ditunjukkan oleh tekstur pembentuk tanah tersebut, tekstur liat atau lempung akan menghasilkan harkat KPK yang tinggi (Wirosoedarmo et. al., 2011). Hal tersebut sesuai dengan Tabel 1 di atas bahwa harkat ketiga sampel memiliki harkat tinggi. Tabel 2 menunjukkan bahwa harkat kation Ca tinggi, Rosmarkam dan Yuwono (2002) menyatakan bahwa unsur Ca dalam tanah mempengaruhi kualitas buah yang dihasilkan. Kondisi tersebut mendukung adanya alternatif pohon buah untuk penghijauan di area perkantoran Pemda Bantul.

\section{Pemilihan Alternatif Pohon Buah}

Daftar alternatif pohon buah didapat dari literatur dan hasil penggalian informasi pada kepala bidang III Dinas Lingkungan Hidup dan kepala seksi produksi bidang tanaman pangan Dinas Pertanian Bantul. Berdasarkan Harjadi et.al. (2010) terdapat ketinggian pohon buah yang sesuai pada pohon buah spesifik. Ketinggian tempat tumbuh tanaman menyebabkan terjadinya variasi baik sumber di dalam tanah maupun sumber di atas tanah (Alam, 2014).

Seleksi I yang digunakan pada Gambar 1.1 merupakan hasil skoring analisis kesesuaian lahan yang dilakukan pada kualitas dan karakteristik lahan dan kriteria kesesuaian tanaman spesifik. Pohon buah dengan kelas kesesuaian lahan aktual S3 tidak dilanjutkan ke seleksi berikutnya, sedangkan pohon buah dengan kelas kesesuaian lahan aktual S1 dan S2 merupakan pohon buah terseleksi yang akan 
Yogyaning Kartiko Atmojo et al., / Vegetalika. 2018. 7(4): 74-88

dilanjutkan ke seleksi berikutnya. Kelas kesesuaian lahan aktual S3 membutuhkan biaya yang tinggi untuk mengingkatkan pada kelas dengan pembatas ringan (S1) maupun faktor pembatas sedang (S2). Kondisi tersebut merupakan refleksi dari penggunaan pohon buah itu sendiri, dimana pohon buah sebagai penghijauan tidak bertujuan utama ke profit yang dihasilkan. 
Yogyaning Kartiko Atmojo et al., / Vegetalika. 2018. 7(4): 74-88

Alternatif Pohon Buah untuk

Penghijauan berdasar studi literatur

1. Alpukat (Persea americana)

2. Asam Jawa (Tamarindus indica)

3. Belimbing Buah (Averrhoa carambola)

4. Belimbing wuluh (Averrhoa bilimbi)

5. Duku (Lansium domesticum)

6. Durian (Durio zibethinus)

7. Jamblang (Syzygium cumini)

8. Jambu Air (Eugenia aquea)

9. Jambu Biji (Psidium guajava $L$.)

10. Jambu Dersono (Eugenia malaccensis)

11. Jeruk manis (Citrus sp.)

12. Jeruk Bali (Citrus grandisty)

13. Jeruk Limau (Citrus amblycarpa)

14. Jeruk Nipis (Citrus aurantifolia)

15. Jeruk Purut (Citrus hystrix)

16. Kakao (Theobroma cacao)

17. Kapulasan (Nephelium mutabile)

18. Kecapi (Sandoricum koetjape)

19. Kedondong (Spondias cythere)

20. Kepel (Stele chocarpus burahol)

21. Kesemek (Diospyros kaki LINN)

22. Kepayang / Kluwek (Pangium edule)

23. Kweni (Mangifera odorata)

24. Lengkeng (Euphoria longan)

25. Manggis (Garcinia mangostana)

26. Melinjo (Gnetum Gnemon LINN)

27. Nangka (Artocarpus heterophylla)

28. Pakel (Mangifera foetida)

29. Pala (Myristica fragrans)

30. Rambutan (Nephelium lappaceum)

31. Sawo duren (Chrysophyllum cainito)

32. Sirsak (Annona muricata)

33. Srikaya (Annona squamosa)

34. Sukun (Artocarpus altilis)

\begin{tabular}{|c|c|}
\hline & Hasil Seleksi 1 (Kesesuaian Lahan) \\
\hline $\begin{array}{c}\text { Hasil seleksi } 1 \\
\text { merupakan seleksi } \\
\text { alternatif pohon buah } \\
\text { terhadap kesesuaian } \\
\text { lahan (SYS et. al., } \\
\text { 1993) dengan syarat } \\
\text { kelas kesesuaian } \\
\text { lahan aktual S1 dan } \\
\text { S2 sebagai pohon } \\
\text { buah terseleksi } \\
\end{array}$ & $\begin{array}{ll}\text { 1. } & \text { Alpukat (Persea americana) } \\
\text { 2. } & \text { Asam Jawa (Tamarindus indica) } \\
\text { 3. } & \text { Belimbing Buah (Averrhoa carambola) } \\
\text { 4. } & \text { Belimbing wuluh (Averrhoa bilimbi) } \\
\text { 5. } & \text { Duku (Lansium domesticum) } \\
\text { 6. } & \text { Durian (Durio zibethinus) } \\
\text { 7. } & \text { Jamblang (Syzygium cumini) } \\
\text { 8. } & \text { Jambu Air (Eugenia aquea) } \\
\text { 9. } & \text { Jambu Biji (Psidium guajava L.) } \\
\text { 10. } & \text { Jambu Dersono (Eugenia malaccensis) } \\
\text { 11. } & \text { Jeruk manis (Citrus sp.) } \\
\text { 12. } & \text { Jeruk Bali (Citrus grandisty) } \\
\text { 13. } & \text { Jeruk Limau (Citrus amblycarpa) } \\
\text { 14. } & \text { Jeruk Nipis (Citrus aurantifolia) } \\
\text { 15. } & \text { Jeruk Purut (Citrus hystrix) } \\
\text { 16. } & \text { Kakao (Theobroma cacao) } \\
\text { 17. } & \text { Kapulasan (Nephelium mutabile) } \\
\text { 18. } & \text { Kecapi (Sandoricum koetjape) } \\
\text { 19. } & \text { Kepel (Stele chocarpus burahol) } \\
\text { 20. } & \text { Kesemek (Diospyros kaki LINN) } \\
\text { 21. } & \text { Kepayang / Kluwek (Pangium } \\
\text { 22. } & \text { Lengkeng (Euphoria longan) } \\
\text { 23. } & \text { Melinjo (Gnetum Gnemon LINN) } \\
\text { 24. } & \text { Nangka (Artocarpus heterophylla) } \\
\text { 25. } & \text { Rambutan (Nephelium lappaceum) } \\
\text { 26. } & \text { Sawo duren (Chrysophyllum cainito) } \\
\text { 27. } & \text { Sirsak (Annona muricata) } \\
\text { 28. } & \text { Srikaya (Annona squamosa) } \\
\text { 29. } & \text { Sukun (Artocarpus altilis) } \\
\end{array}$ \\
\hline
\end{tabular}

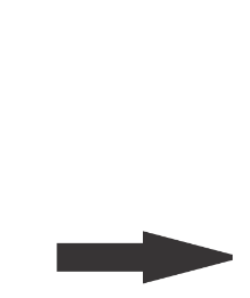

Hasil seleksi 2

merupakan seleksi alternatif pohon buah terhadap Permen PU

no 5 tahun 2008

tentang penyediaan

RTH di perkotaan

khusunya di

perkantoran
Hasil Seleksi 2 (Karakteristik tanaman perkantoran Permen PU no 5/2008

Alpukat (Persea americana)

2. Asam Jawa (Tamarindus indica)

3. Belimbing Buah (Averrhoa

4. Belimbing wuluh (Averrho

5. Duku (Lansium domesticum)

6. Jamblang (Syzygium cumini)

7. Jambu Air (Eugenia aquea)

8. Jambu Biji (Psidium guajava $L$.)

9. Jambu Dersono (Eugenia malaccensis)

10. Kakao (Theobroma cacao)

11. Kapulasan (Nephelium mutabile)

12. Kepel (Stele chocarpus burahol)

13. Lengkeng (Euphoria longan)

14. Melinjo (Gnetum Gnemon LINN)

15. Nangka (Artocarpus heterophylla)

16. Rambutan (Nephelium lappaceum)

17. Sawo duren (Chrysophyllum cainito)

18. Sirsak (Annona muricata)

19. Srikaya (Annona squamosa) 
Diketahui bahwa terdapat 5 alternatif pohon buah buah yang bernilai kelas S3 yaitu Pala (Myristica fragrans), Pakel (Mangifera foetida), Kweni (Mangifera odorata), Manggis (Garcinia mangostana), dan Kedondong (Spondias cythere). Dengan adanya 5 pohon buah yang tidak sesuai sehingga didapati 29 pohon buah terseleksi. Secara umum, faktor-faktor pembatas terberat :

a. Ketersediaan air (wa)

Untuk lebih memperkecil dampak dari faktor pembatas tersebut dapat dilakukan upaya perbaikan. Upaya perbaikan irigasi yang dimaksudkan adalah pada pengoptimalan drainase tanah. Perbaikan drainase dengan lubang resapan biopori dapat mengatasi genangan yang kemungkinan akan timbul sehingga kebutuhan air untuk pohon buah dapat terpenuhi pada kecukupannya.

b. Ketersediaan Hara (na)

Fungsi hara tanaman tidak dapat digantikan oleh unsur lain dan apabila tidak terdapat suatu hara tanaman maka kegiatan metabolism akan terganggu. Apabila ditinjau dari ketersediaan hara makro $\mathrm{N}, \mathrm{P}, \mathrm{K}$ hanya unsur $\mathrm{N}$ yang memiliki harkat rendah. Rosmarkam dan Yuwono (2002) menyatakan bahwa hasil analisis tanah pada hara tersedia yang berharkat rendah menyebabkan pertumbuhan tanaman sedikit terganggu dan rentan hama penyakit. Oleh karena itu dilakukan upaya perbaikan dengan pemupukan.

c. Retensi Hara (nr)

Anasir yang menjadi faktor pembatas pada kriteria alternatif pohon buah adalah kejenuhan basa, $\mathrm{pH}$ dan $\mathrm{C}$-organik. $\mathrm{pH}$ sebagai faktor pembatas pohon buah dapat diupayakan untuk diperbaiki dengan dilakukan pengapuran. Upaya perbaikan pada kandungan C organik dinyatakan Sanchez (1992) bahwa tambahan bahan organik akan meningkatkan $\mathrm{C}$ organic dalam tanah. Sehingga aplikasi bahan organik merupakan upaya perbaikan yang dapat dilakukan untuk menaikkan dari kelas S2 menjadi S1.

d. Temperatur rerata pada masa pertumbuhan (tc)

Temperatur atau suhu merupakan anasir iklim yang dalam upaya perbaikanya tidak dapat dilakukan. Nilai dari suhu merupakan gambaran secara kompleks dalam ekosistem pembentuknya sehingga untuk memodifikasi membutuhkan atas segala aspek.

Pohon buah alternatif yang terseleksi pada kesesuaian lahan (seleksi I) akan dilanjutkan ke seleksi berikutnya (seleksi II). Seleksi II merupakan 
Yogyaning Kartiko Atmojo et al., / Vegetalika. 2018. 7(4): 74-88

modifikasi dari peraturan menteri pekerjaan umum nomor 5 tahun 2008 tentang penyediaan ruang terbuka hijau khususnya perkantoran yaitu

a. sistem perakaran masuk ke dalam tanah, tidak merusak konstruksi bangunan;

b. tidak beracun, tidak berduri, dahan tidak mudah patah, perakaran tidak mengganggu pondasi;

c. ketinggian tanaman bervariasi, warna hijau dengan variasi warna lain seimbang;

d. tahan terhadap hama penyakit tanaman;

e. mampu menyerap cemaran udara;

Pada tahap ini didapati bahwa 10 pohon buah tidak memenuhi persyaratan sebagai penghijauan di perkantoran. Pohon buah tersebut antara lain Durian (Durio zibethinus), jeruk manis (Citrus sp.), jeruk bali (Citrus grandisty / C. maxima), jeruk limau (Citrus amblycarpa), jeruk nipis (Citrus aurantifolia), jeruk purut (Citrus hystrix), Kecapi (Sandoricum koetjape (Burm. F.) Merr), Kepayang (Pangium edule REINW), Sirsak (Annona muricata), sukun (Artocarpus altilis), dan kesemek (Diospyros kaki LINN)

Parameter pohon buah yang tidak memenuhi persyaratan pada dahan/ranting adalah pohon buah Kecapi (Sandoricum koetjape (Burm. F.) Merr), Kedondong (Spondias cythere), Kepayang (Pangium edule REINW), dan sukun (Artocarpus altilis) (Pitojo dan Puspita, 2007; Saptono, 2013; Sukewijaya et. al.,2015; Nabila, 2017). Dahan/ranting yang mudah patah berbahaya bagi lingkungan sekitar yang dapat membahayakan tamu maupun fasilitas. Pohon buah yang memiliki duri pada organ tanamannya antara lain Durian (Durio zibethinus), jeruk manis (Citrus sp.), jeruk bali (Citrus grandisty / C. maxima), jeruk limau (Citrus amblycarpa), jeruk nipis (Citrus aurantifolia), dan jeruk purut (Citrus hystrix). Bagian dari organ tanaman yang berujung tajam dan cukup keras tersebut dapat membahayakan tamu atau pengunjung perkantoran

\section{Rekomendasi Alternatif Pohon Buah area perkantoran Pemda Bantul}

Analisis yang telah dilakukan menuju pada rekomendasi alternatif pohon buah yang dapat digunakan sebagai vegetasi penyusun area perkantoran Pemda Bantul. Dalam perumusan rekomendasi pada penelitian ini berisi alternatif pohon buah untuk penghijauan area perkantoran Pemda Bantul.

Setelah didapati 19 alternatif pohon buah terseleksi, selanjutnya dilakukan penggalian informasi yang berfungsi sebagai data pendukung 
Yogyaning Kartiko Atmojo et al., / Vegetalika. 2018. 7(4): 74-88

perumusan rekomendasi. Hal ini dilakukan untuk mengkaji pohon buah dari hasil analisis yang paling potensial dan bermanfaat untuk penghijauan di area perkantoran Pemda Bantul. Sumber informasi adalah pemangku kekuasaan, yakni kepala bidang III Dinas Lingkungan Hidup Bantul dan Kepala bidang Tanaman Pangan Seksi Produksi Dinas Pertanian Bantul.

Penggalian informasi pada Kepala bidang Tanaman Pangan Seksi Produksi Dinas Pertanian Bantul didapati pohon buah sebagai penghijauan di area perkantoran yang dapat digunakan sebagai penciri dari daerah. Asam jawa dan kepel dipilih dengan alasan sebagai penciri orang jawa. Kemudian pohon buah yang tidak dipilih sebagai penghijauan di area perkantoran Pemda Bantul adalah kakao karena menurut beliau kakao merupakan tanaman perkebunan yang mana tanaman perkebunan kurang sesuai digunakan sebagai penamabah estetika.

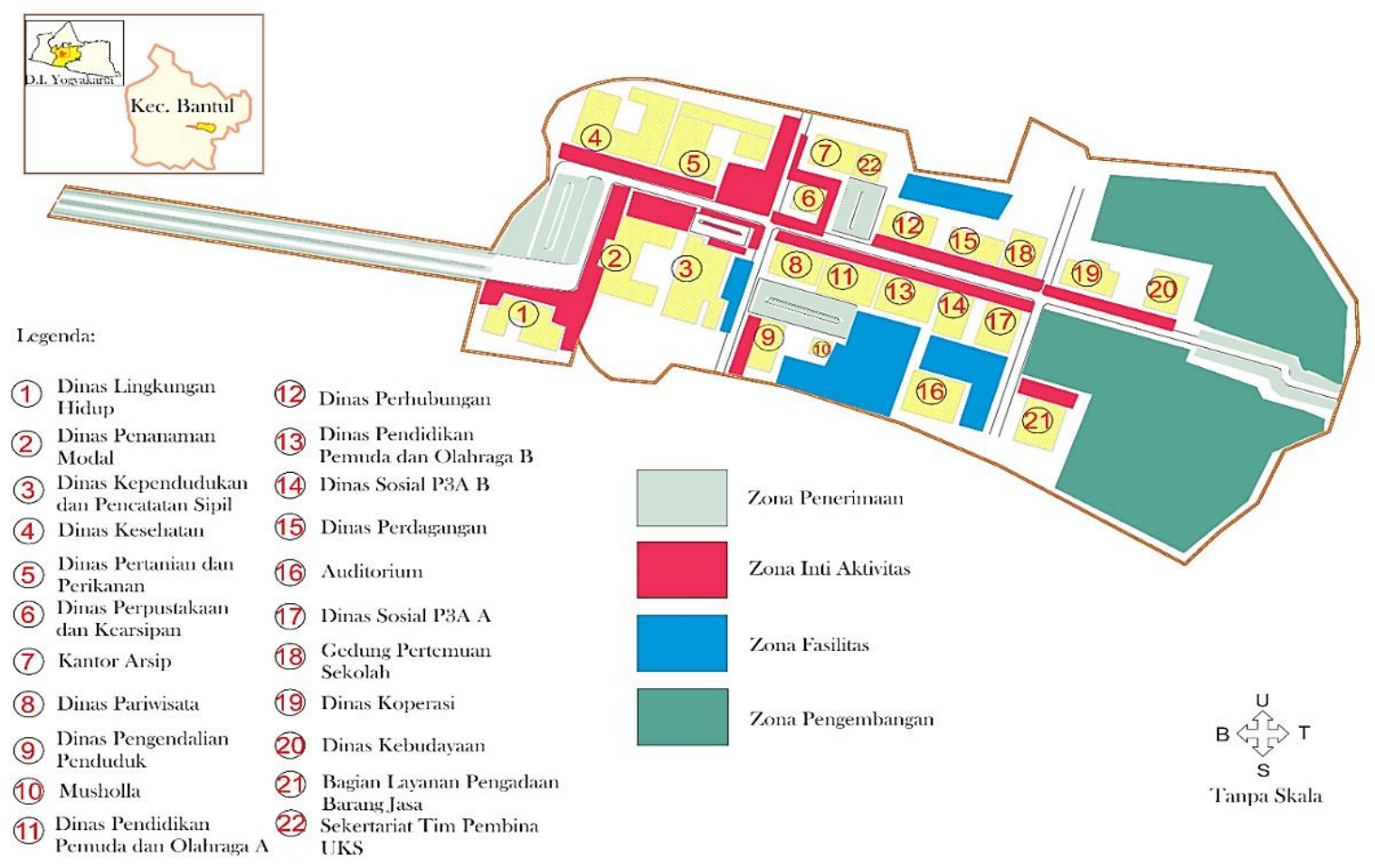

Gambar 2. Pembagian Zona Aktivitas Tamu/Pengunjung Perkantoran

Informasi kedua berasal dari kepala bidang III Dinas Lingkungan Hidup Bantul. Pemilihan pohon buah untuk penghijauan didasari pada tingkat pelestarian plasma nutfah dan keberadaan spesies yang sudah mulai langka. Pohon buah yang sudah umum seperti alpukat, nangka, belimbing, jambu air, 
Yogyaning Kartiko Atmojo et al., / Vegetalika. 2018. 7(4): 74-88

jambu biji, kakao, rambutan, melinjo, dan srikaya tidak akan dipilih sebagai revitalisasi karena sudah banyak dikenal dan ditanam oleh masyarakat.

Dihasilkan 8 pohon buah alternatif penghijauan di area perkantoran Pemda Bantul adalah Asam Jawa (Tamarindus indica), Kepel (Stelechocarpus burahol), Duku (Lansium domesticum), Lengkeng (Euphoria longan), Sawo Duren (Chrysophyllum cainito), Jamblang (Syzygium cumini), Kapulasan (Nephelium mutabile), Jambu dersono (Eugenia malaccensis), alpukat (Persea Americana), dan nangka (Artocarpus heterophylla)

Tabel 3. Rekomendasi alternatif pohon buah berdasarkan zona wilayah

\begin{tabular}{|c|c|c|c|c|}
\hline No & Jenis Zona & Fungsi area & Kriteria Pohon & Alternatif Pohon Buah \\
\hline 1 & Zona Penerima & $\begin{array}{l}\text {-Parkir } \\
\text {-petunjuk } \\
\text { Kedatangan }\end{array}$ & $\begin{array}{l}\text {-Identitas tanaman } \\
\text { lokal } \\
\text {-Buah tidak } \\
\text { berukuran besar } \\
\text {-Habitus tanaman } \\
\text { tinggi } \\
\end{array}$ & $\begin{array}{l}\text { Asam Jawa (Tamarindus } \\
\text { indica), Kepel } \\
\text { (Stelechocarpus burahol), } \\
\text { Duku (Lansium } \\
\text { domesticum) }\end{array}$ \\
\hline 2 & $\begin{array}{l}\text { Zona Inti Aktivitas } \\
\text { Tamu/ } \\
\text { pengunjung } \\
\text { Perkantoran }\end{array}$ & $\begin{array}{l}\text {-Mobilitas } \\
\text { antar Pemda } \\
\text {-Tempat } \\
\text { Antrian }\end{array}$ & $\begin{array}{l}\text { - Pandangan Mata } \\
(1,2 \mathrm{~m}-2 \mathrm{~m}) \\
\text { - kerapatan tajuk } \\
\text { tinggi }\end{array}$ & $\begin{array}{l}\text { Lengkeng } \\
\text { (Euphoria longan), } \\
\text { Sawo Duren } \\
\text { (Chrysophyllum cainito) } \\
\text { Jamblang } \\
\text { (Syzygium cumini) } \\
\text { Kapulasan (Nephelium } \\
\text { mutabile) } \\
\end{array}$ \\
\hline 3 & $\begin{array}{l}\text { Zona Fasilitas } \\
\text { Masyarakat }\end{array}$ & $\begin{array}{l}\text {-Menikmati } \\
\text { Lingkungan } \\
\text { Sekitar } \\
\text {-Sholat } \\
\text {-Makan }\end{array}$ & $\begin{array}{l}\text {-Buah dapat } \\
\text { dikonsumsi secara } \\
\text { langsung } \\
\text {-Peneduh }\end{array}$ & $\begin{array}{l}\text { Duku (Lansium } \\
\text { domesticum), } \\
\text { Jambu dersono (Eugenia } \\
\text { malaccensis), } \\
\text { Sawo Duren } \\
\text { (Chrysophyllum cainito) } \\
\end{array}$ \\
\hline 4 & $\begin{array}{l}\text { Zona } \\
\text { Pengembangan }\end{array}$ & -konservasi & $\begin{array}{l}\text { Tidak memiliki } \\
\text { keriteria khusus }\end{array}$ & $\begin{array}{l}\text { Semua Alternatif Pohon } \\
\text { Buah diatas }\end{array}$ \\
\hline
\end{tabular}

1) Zona penerimaan merupakan area pertama yang menjadi tempat penerimaan tamu/pengunjung perkantoran. Zona ini merupakan bagian muka yang dimiliki oleh area perkantoran Pemda Bantul sehingga apa yang terlihat pada bagian ini menimbulkan kesan pertama bagi setiap tamu yang hadir. Untuk menciptakan kesan yang baik pada zona penerimaan maka diperlukan pohon yang dapat menjadi identitas daerah yang sedang disinggahi. Alternatif pohon 
Yogyaning Kartiko Atmojo et al., / Vegetalika. 2018. 7(4): 74-88

buah yang dapat dimanfaatkan pada zona ini adalah Asam jawa (Tamarindus indica), Kepel (Stelechocarpus burahol).

2) Zona inti aktivitas tamu/pengunjung perkantoran adalah zona yang merupakan tujuan utama kedatanganya tamu/pengunjung perkantoran, aktivitas pada zona ini memang lebih banyak dilakukan dalam bangunan. Akan tetapi ruang luar pada zona ini adalah akses untuk menuju ke dalam bangunan sehingga pembentukan ruang luar harus sedemikian rupa di rencanakan agar dapat kondusif. Pohon buah dapat memberikan fungsi tambah dalam zona ini. Alternatif pohon buah yang dapat dimanfaatkan adalah Lengkeng (Euphorialongan), Jamblang (Syzygium cumini), dan Kapulasan (Nephelium mutabile).

3) Zona fasilitas masyarakat merupakan zona ruang terbuka yang banyak dimanfaatkan untuk meluangkan waktu dari aktivitas inti. Area ini umumnya digunakan untuk mencari suasana segar dan sejuk dan menunaikan kewajiban agama. Sehingga pembentukan ruang terbuka pada zona ini diupayakan untuk memberikan suasana nyaman sebagaimana fungsi dari area ini. Alternatif pohon buah yang dapat dimanfaatkan untuk wilayah ini adalah pohon buah yang dapat dipetik dan dikonsumsi secara langsung antara lain Duku (Lansium domesticum), Jambu dersono (Eugenia malaccensis). Untuk menciptakan suasana nyaman diperlukan pohon dengan kerapatan tajuk tinggi sehingga persentase cahaya matahari yang tertahan oleh tajuk besar, pohon buah tersebut adalah Sawo Duren (Chrysophyllum cainito).

4) Zona pengembangan adalah wilayah yang belum difungsikan untuk area perkantoran Pemda Bantul. Zona ini merupakan zona yang tidak dapat diakses oleh tamu perkantoran atau hanya dapat dilihat dari jarak jauh sehingga difungsikan sebagai zona pengembangan yang mempunyai fungsi sebagai konservasi.

\section{KESIMPULAN}

Area Perkantoran Pemda Bantul sesuai untuk digunakan sebagai penghijauan dengan 86lternative pohon buah. Terdapat 86lternative pohon buah yang sesuai untuk digunakan sebagai penghijauan di Area perkantoran Pemda Bantul. Alternatif pohon buah pada zona penerimaan antara lain Asam Jawa (Tamarindus indica), Kepel (Stelechocarpus burahol), Duku (Lansium domesticum). Kemudian pada zona inti aktivitas direkomendasikan 86lternative 
Yogyaning Kartiko Atmojo et al., / Vegetalika. 2018. 7(4): 74-88

pohon buah Lengkeng (Euphoria longan), Sawo Duren (Chrysophyllum cainito), Jamblang (Syzygium cumini), dan Kapulasan (Nephelium mutabile). Selanjutnya pada zona fasilitas masyarakat direkomendasikan 87lternative pohon buah Jambu dersono (Eugenia malaccensis), dan Duku (Lansium domesticum)

\section{DAFTAR PUSTAKA}

Alam, T. 2014. Optimalisasi Pengelolaan Sistem Agroforestri Cengkeh, Kakao, dan Kapulaga di Pegunungan Menoreh. Tesis. Universitas Gadjah Mada, Yogyakarta

Beer, A.R. 1990. Enviromental Planning for Site Development. Library of Congress Cataloging. United Kingdom

Carpenter, P.L., T.D. Walker and F.O. Lanphear. 1975. Plants in the Landscape. W.H. Freeman and Company, New York

Danoesastro, H. 1976. Pohon Buah-Buahan. Penataan Purna Sarjana IImu Hortikultura Fakultas Pertanian UGM, Yogyakarta

Dunnet, Swanwick, C. and H. Woolley. 2002. Improving Urban Parks, Play Areas and Open Spaces. Department of Landscape, University of Sheffield. London.

Lab Perencanaan Lanskap, Dept. Arsitektur Lanskap, Institut Pertanian Bogor (2005), Ruang Terbuka Hijau di Wilayah Perkotaan, <http://www.penataa nruang.net /taru/Makalah/051130-rth.pdf>, diunduh 10 September 2017

Lisandru, T.T, Mitre, V. and K. Kimic. 2016. Identification of fruit tree compositions in public parks structure. Warsaw case study. Bulletin UAVSM Horticulture 73:2

Miles, M.B, Huberman, A.M, (1994). Qualitative data analysis, 2nd ed. Sage Publication, USA

Nabila, C.A. 2017. Alternatif Pohon Buah Untuk Penghijauan Permukiman Perkotaan Berdasarkan Kesesuaian Lahan dan Pendugaan Tingkat Keindahan SBE di Kelurahan Rejowinangun. Universitas Gadjah Mada Yogyakarta. Skripsi

Ritung, S., K. Nugroho, A. Mulyani, dan E. Suryani. 2011. Petunjuk Teknis Evaluasi Lahan Untuk Komoditas Pertanian (Edisi Revisi). Balai Besar Penelitian dan Pengembangan Sumberdaya Lahan Pertanian, Badan Penelitian dan Pengembangan Pertanian, Bogor. 168 hal.

Rosmarkam, A dan N. W. Yuwono. 2002. Ilmu Kesuburan Tanah. Penerbit Kanisus, Yogyakarta 
Yogyaning Kartiko Atmojo et al., / Vegetalika. 2018. 7(4): 74-88

Sanchez, P.A. 1992. Sifat dan pengelolaan tanah tropika. Terjemahan Properties and Management in The Tropics. ITB, Bandung

Sys, C., E. V. Ranst dan J. Debaveye. 1993. Land Evaluation part III Crop Requirements. General Administratin for Development Cooperation Place de Champ de Mars 5 bte 57 - 1050 Brussels - Belgium.

Wirosoedarmo, R., Sutanhaji, A.T., Kurniati, E. dan R. Wijayanti. 2011. Evaluasi kesesuaian lahan untuk tanaman jagung menggunakan metode analisis spasial. Jurnal Agritech 31(1):71-78 